\title{
Usos E ABUSOS DA ANTIGÜIDADE CLÁSSICA: SOBRE A APROPRIAÇÃO DO CINISMO GREGO NA DESCRIÇÃO CONTEMPORÂNEA DE DISTÚRBIOS PSÍQUICOS*
}

\author{
Olimar Flores-Júnior \\ UFMG
}

\begin{abstract}
RESUMO
Examinando particularmente a "síndrome de Diógenes" e a idéia de "gozo cínico" aplicado na tipificação do toxicômano das sociedades pós-modernas, este artigo retoma de maneira breve e sucinta o problema da leitura e das apropriações da antigüidade clássica na caracterização de fenômenos culturais contemporâneos (ou pelo menos descritos na contemporaneidade). Sem qualquer intenção crítica diante dos fenômenos descritos, já que a perspectiva adotada é a da história da filosofia e não a do domínio específico da psiquiatria e da psicanálise, busca-se apenas demonstrar, através de uma remissão sistemática ao texto das fontes antigas - neste caso, ao corpus cínico -, os limites metodológicos e os conseqüentes equívocos em que tal prática pode incorrer.

\section{PALAVRAS - CHAVE}

Cinismo, Diógenes de Sínope, "Síndrome de Diógenes", "Gozo Cínico”, Psiquiatria, Psicanálise, História da Filosofia, Apropriação.
\end{abstract}

"Sábado fez quinta-feira, domingo fez três semanas, que pariu a porca um burro, mas com vinte e cinco mamas". Joaquim José da Silva, o Sapateiro Silva

\begin{abstract}
Tomar de empréstimo elementos da antigüidade clássica - mitos, personagens, eventos - para descrever, no contexto da civilização ocidental, fenômenos e fatos contemporâneos sempre foi prática corrente, indissociável mesmo daquilo que, de maneira abrangente, chamamos "cultura". Tal prática reverbera, na atualidade do discurso, o passado que institui
\end{abstract}

* Este trabalho foi elaborado no quadro de uma pesquisa mais ampla que contou com o apoio do CNPq. Agradeço ao Dr. Musso Garcia Greco, com quem pude discutir alguns aspectos do tema que abordo aqui e a quem devo a indicação de alguns títulos da bibliografia médica e psicanalítica utilizados. Agradeço ainda a Maria Cecília Bruzzi Boechat, que releu estas páginas e graças a quem meu eventual leitor terá sob os olhos um texto melhor; as imprecisões que porventura permanecem deverão ser imputadas à minha ignorância ou à minha teimosia. 
e garante a identidade de um universo compartilhado. Falamos então de tragédia para designar um acidente de grandes proporções e graves conseqüências, de uma atitude narcisista, de uma discussão homérica ou de um comportamento estóico e estamos certos de sermos compreendidos - nós que somos, como já se escreveu, a "posteridade útil" do mundo grecoromano. ${ }^{1}$ Sem qualquer explicação acessória, a língua comum evoca in promptu a exemplaridade das experiências ancestrais recortadas segundo os moldes que a história lhe impõe, e garante assim autoridade e eficácia aos seus enunciados.

De forma análoga, também o discurso científico se vale do mesmo procedimento, abrigando, contudo, uma variação importante na pertinência da apropriação, o que depende do rigor metodológico aplicado. Nesse sentido, o caso mais célebre - e de longe o mais polêmico, dada a riqueza dos aspectos implicados - é certamente o do "complexo de Édipo", mencionado pela primeira vez por Freud em 1900, quando da publicação de uma de suas principais obras, Die Traumdeutung. Nela, o neurologista e psiquiatra austríaco se apropriava da lenda grega de Édipo para sistematizar o diagnóstico dos distúrbios de alguns de seus pacientes. Tem-se aí a fundação da psicanálise que suscitou, para além de todo o debate em torno de sua validade médica - pois a nova disciplina surge já intimamente associada a uma prática clínica -, uma outra ordem de problemas que interessam sobretudo à história das idéias, mais especificamente à história da interpretação dos mitos e à psicologia histórica, e que foram formulados nos termos de uma única pergunta: "em que medida uma obra literária que pertence à cultura da Atenas do quinto século a.C., e que transpõe de maneira muito livre uma lenda tebana muito mais antiga, anterior ao regime da cidade, pode confirmar as observações de um médico do começo do século XX sobre a clientela de doentes que freqüentavam o seu consultório?". ${ }^{2}$ Do ponto de vista da psicanálise, tal pergunta, como o seu próprio autor reconhece, não exige resposta, pois nem deveria ser feita, já que "a interpretação do mito e do drama gregos de maneira nenhuma constitui problema" para o psicanalista, uma vez que "eles não precisam ser decifrados por métodos de análise apropriados", revelando "de uma só vez uma significação cuja evidência traz às teorias psicológicas do clínico uma garantia de validade universal". ${ }^{3}$ Tal justificativa, que antecipa a crítica à abordagem freudiana do mito de Édipo, postula a incompatibilidade metodológica entre a perspectiva psicanalítica e a psicologia histórica, mas acusa, no mesmo movimento, a primeira de, incorrendo ilegitimamente na história da literatura e negligenciando todo rigor filológico, querer se substituir à segunda. Os argumentos dessa crítica levantam uma outra questão necessária: o que, de fato, pode garantir a legitimidade da apropriação, considerados os fins a que ela se destina? Caberia ainda, nesse sentido, rearranjando os elementos da própria crítica e considerando o terreno mais amplo dos processos de constituição da cultura, perguntar se, de algum modo, a interpretação freudiana do mito de Édipo não estaria para a tragédia de Sófocles como está para a lenda tradicional, a trama que o poeta põe em cena. ${ }^{4}$

\footnotetext{
${ }^{1}$ N. Saldanha, "Os clássicos e a exemplaridade histórica".

2 J.-P. Vernant, "Édipo sem complexo", p. 77.

${ }^{3}$ Ibid., p. 78.

${ }^{4}$ A bibliografia sobre o mito de Édipo é, não só vasta, como variada; citaria apenas a obra monumental de J. Bollack, L'“Edipe Roi" de Sophocle. Le texte et ses interprétations; posteriormente o mesmo autor retoma o tema em um único volume: J. Bollack, La naissance d'Edipe. Traduction et commentaires d' "EEdipe Roi".
} 
Após essa breve introdução em que, através dos exemplos utilizados, julgo haver determinado o lugar de onde falo, passo a ocupar-me dos dois casos de apropriação da antigüidade que constituem de fato o objeto de minhas considerações, a saber: a "síndrome de Diógenes" e o conceito de "gozo cínico", aplicado, este último, na descrição do comportamento do toxicômano nas sociedades contemporâneas. Em ambos os casos, tratase de uma apropriação do Cinismo antigo, escola filosófica surgida na Atenas do século IV a.C. e que tem na figura de Diógenes de Sínope seu principal representante. Apesar de estarem outra vez implicadas, tanto num caso como no outro, disciplinas como a psiquiatria e a psicanálise, estamos longe da complexa elaboração interpretativa a que Freud submeteu o mito de Édipo: em primeiro lugar pela própria natureza da teoria freudiana, que visa à universalidade e, em segundo lugar, porque toda apropriação do cinismo evoca não um mito, mas uma tradição filosófica datada e, sobretudo, uma personagem histórica, cuja biografia, por mais obscuros e controversos os elementos que a constituem, repousa sobre uma base factual. Que se possa ou não apreender, com alguma segurança, os elementos dessa tradição é um debate que pertence ao domínio da filologia, da crítica textual e da interpretação filosófica, e não ao da mitologia (embora alguns instrumentos de análise próprios desta última possam ser aproveitados num estudo historiográfico, como por exemplo na elaboração de uma "prosopografia" do cinismo antigo). Assim, se no contexto da história da filosofia falamos em uma "lenda de Diógenes", nos referimos apenas, com o empréstimo do termo, à dificuldade de se extrair de uma vasta literatura - mas essencialmente fragmentária, doxográfica e anedótica - um perfil nítido e coerente do filósofo e do homem que foi Diógenes, dificuldade essa que, a exemplo do que ocorre com outras personagens históricas, tais como Jesus ou Sócrates, contrasta com a importância que lhe concede a tradição literária e filosófica da Antigüidade. ${ }^{5}$

A "síndrome de Diógenes", descrita pela primeira vez em 1975, inclui-se no grupo das psicopatologias implicando um transtorno das condutas sociais, e acomete principalmente pessoas idosas, acima dos 65 anos, com um histórico pessoal de isolamento, solidão e, muitas vezes, antecedentes de luto ocorrido já na velhice. ${ }^{6}$ Essas pessoas, que na maioria dos casos conservaram sua autonomia, são identificadas fortuitamente quando de uma hospitalização por alguma doença aguda intercorrente ou com a revelação de suas condições de vida pela família, ou ainda através da reclamação de vizinhos pelo incômodo oriundo do fedor ou da presença de parasitas nas imediações do lugar em que vivem. Constatou-se nesses indivíduos

\footnotetext{
${ }^{5}$ Veja-se, por exemplo, a introdução ("The problem of the Cynics") de R. Höistad, Cynic hero and cynic king, p. 5-21, onde o autor se refere à so called Diogenes legend (p. 17). Em duas outras ocasiões

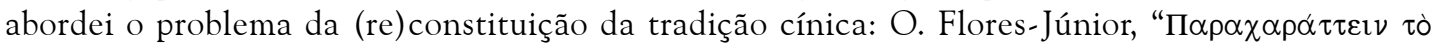
$\nu \sigma\langle\iota \sigma \mu \alpha$ ou as várias faces da moeda" e id., "Sobre o problema das fontes no estudo do cinismo antigo."

${ }^{6}$ A.N. Clark, G. Mankikar e E.D. Gray, "Diogenes syndrome: a clinical study of gross neglect in old age". Registra-se, entretanto, que alguns anos antes D. MacMillan e P. Shaw, Senile breakdown in standards of personnal and environnemental cleanliness, descreveram uma situação clínica semelhante a partir do estudo de pessoas idosas que tinham por traço comum viver isoladamente em condições degradadas de higiene pessoal e doméstica; naquela ocasião, o quadro clínico descrito foi denominado "síndrome de descompensação senil". Sobre os aspectos médicos da "síndrome de Diógenes", cf. ainda V. Léon, K. Rannou-Dubas, J. Barré, B. Gohier, J.L. Goeb e J.B. Garre, "Un collectionnisme singulier: le syndrome de Diogène", que oferece uma longa bibliografia e de que eu amplamente me sirvo.
} 
a recorrência de certos traços comportamentais que foram associados à imagem do filósofo grego e, a partir daí, tentou-se estabelecer o quadro clínico da então batizada "síndrome de Diógenes”, que combinaria as seguintes características: uma negligência extrema da higiene corporal e do domicílio (cuja visita obviamente auxilia na confirmação do diagnóstico); uma syllogomania, que corresponde a um colecionismo mórbido de objetos heteróclitos (latas, caixas, revistas e jornais velhos, roupas sem uso, restos de comida em deterioração, excrementos, cadáveres de animais em putrefação); uma negação da realidade e uma ausência de vergonha relativa à sua condição de vida; isolamento social voluntário; uma personalidade pré-mórbida: desconfiada, maliciosa, distante, com tendência a deformar os fatos; uma recusa de qualquer ajuda, percebida sempre como invasiva; ausência de alterações cognitivas. Acrescenta-se enfim que os casos observados não indicam qualquer relação com problemas financeiros, uma vez que os sujeitos concernidos apresentam normalmente uma renda suficiente para uma vida correta, não sendo raros os casos de pacientes "Diógenes" - assim eles aparecem referidos na bibliografia médica - apresentando uma situação financeira confortável.

Entretanto, para a psiquiatria, a "síndrome de Diógenes" ainda levanta problemas no que diz respeito à avaliação objetiva desse seu quadro clínico e, principalmente - já que se trata de uma síndrome, ou seja, de um "estado mórbido caracterizado por um conjunto de sinais e sintomas, e que pode ser produzido por mais de uma causa" (do substantivo grego

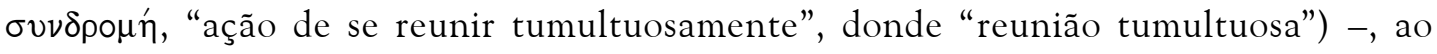
estabelecimento consensual de sua etiologia. Nesse debate, duas correntes principais parecem coexistir: uma que acusa nesses pacientes uma real patologia psiquiátrica, ligada a outras formas de distúrbios, tais como demência (que poderia ser explicada por um disfunção do lóbulo frontal do cérebro), alcoolismo, parafrenia, esquizofrenia e transtorno obsessivocompulsivo (TOC); a outra corrente, não reconhecendo nesse tipo de comportamento nenhuma patologia psiquiátrica e insistindo na ausência de alteração cognitiva, sustenta a hipótese de que a "síndrome de Diógenes" corresponderia, na verdade, a uma reação ao estresse específica da pessoa idosa, incidindo sobre uma personalidade já predisposta, comportando traços de ansiedade, humor depressivo e tendência à introspecção; dessa perspectiva a referida síndrome seria uma atitude ativa e não uma degradação passiva. A questão de fundo que o debate médico coloca é, portanto, a de saber se estamos diante da manifestação de uma patologia psiquiátrica podendo evocar uma conduta delirante de tipo paranóico ou da escolha de um modo de vida refletindo a expressão do livre arbítrio, à imagem de Diógenes.

Mas para o historiador da filosofia, o que constitui problema é a identificação do tipo de comportamento comum aos indivíduos "Diógenes" com a imagem do filósofo grego, cuja biografia se (con)funde com a própria doutrina cínica. ${ }^{7}$ Nesse sentido, uma rápida consulta à

${ }^{7}$ Essa (con)fusão entre a biografia do filósofo e a sua filosofia corresponde a uma das mais importantes características da tradição cínica: a precedência da ação sobre o discurso. No plano das formas literárias e da transmissão material do pensamento, a anedota, o apophthegma e a chreia substituem o corpus teorético nas suas diversas manifestações (tratados, poemas, diálogos). Com o seu próprio exemplo, Diógenes valida a opinião de Antístenes, para quem "a virtude diz respeito às ações (ع $(\mu \alpha \theta \eta \mu \alpha \tau \tau \omega)$ " (Diógenes Laércio, Vidas e doutrinas dos filósofos ilustres [abreviado a partir daqui em D.L.] VI 11; todas as traduções do grego, salvo indicação contrária, foram feitas por mim

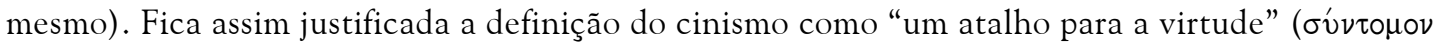


literatura sobre o cinismo e, em particular, sobre Diógenes que a Antigüidade nos legou bastaria para comprovar o equívoco da apropriação. ${ }^{8}$ Fica, por exemplo, difícil - se não impossível - conciliar a syllogomania dos "Diógenes modernos", que parece ser o mais característico dos sintomas que compõem a síndrome, ${ }^{9}$ com a austeridade e o despojamento do Diógenes histórico, que Diógenes Laércio, autor que viveu provavelmente no século III d.C., ilustra nos seguintes termos:

Um dia, tendo visto um garotinho que bebia usando as próprias mãos, ele [Diógenes] tira da sacola sua caneca e joga-a fora, dizendo: "um garotinho me venceu em matéria

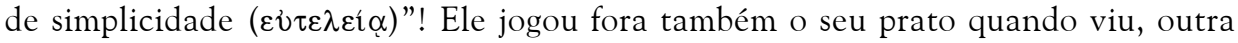
vez, um garotinho que, tendo quebrado sua gamela, ajuntava no oco de um pedaço de pão sua porção de lentilhas. ${ }^{10}$

Nada há nessa passagem que evoque, de perto ou de longe, qualquer tipo de demência ou perturbação. Ao contrário, o texto laerciano mostra o cínico agindo segundo uma lógica implacável, que visa, no rigor da ascese, a redução dos desejos humanos ao necessário e a das necessidades ao mínimo. O gesto de Diógenes é, talvez, excessivo, mas na direção contrária do que pretende a justificativa da denominação da "síndrome de Diógenes". Além disso, vale notar que o excesso do filósofo tem um valor pedagógico: o próprio Diógenes dizia imitar os mestres de coro, que dão o tom um tom acima para que os demais encontrem o tom

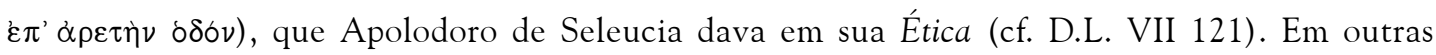
palavras, pode-se dizer que o filósofo cínico emerge da literatura antiga como uma persona philosophica que "representa" a própria filosofia. Os fragmentos relativos aos cínicos foram reunidos por G. Giannantoni, Socratis et socraticorum reliquiae, collegit, disposuit, apparatibus notisque instruxit G. Giannantoni, Napoli, 1990, 4 v. (para os fragmentos relativos aos cínicos, consultar o vol. II), abreviado a partir daqui na forma já usual, SSR, seguida da indicação do fragmento; registre-se ainda a coletânea em tradução francesa elaborada por L. Paquet, Les Cyniques grecs: fragments et témoignages. Da bibliografia geral sobre o cinismo, destacaria aqui dois títulos: o sempre útil D.R. Dudley, A history of Cynicism e o indispensável M.-O. Goulet-Cazé, Lascèse cynique. Un commentaire de Diogène Laërce VI 70-71.

${ }^{8}$ Tal equívoco começa a ser reconhecido, ainda que aparentemente de forma marginal, pela bibliografia médica. Em artigo do Bulletin d'Information en Santé Environnementale (BISE), publicado pelo Instituto Nacional de Saúde Pública do Quebec, lê-se: "En fait, la dénomination de ce syndrome est impropre car Diogène, ce philosophe grec du quatrième siècle avant Jésus-Christ, préconisait l'autosuffisance avec un minimum de ressources. (...) Certains auteurs suggèrent de dénommer cette ateinte 'syndrome de l'auto-négligence sévère du vieillard' (The Self-neglect Elderly)" (p. 3). Aliás, o mesmo artigo observa que "quoique ce comportement soit rapporté et bien documenté dans la littérature scientifique, il n'existe aucun diagnostic psychiatrique portant l'appelation de syndrome de Diogène dans le Manuel diagnostique et statistique des troubles mentaux (DSM - IV)" (p. 2).

${ }^{9}$ Há uma tendência, na literatura médica, de se classificar o indivíduo apresentando as características da "síndrome de Diógenes" na categoria dos "acumuladores patológicos". Para O. Saladini e J.P. Luaute, "Le collectionnisme des entasseurs pathologiques", citado por V. Léon et alii, "Un collectionnisme singulier...", cit., a acumulação seria um "sintoma transnosográfico" que pode ser observado nos sujeitos acometidos de transtornos obsessivo-compulsivos, esquizofrenias, demências, "síndrome de Diógenes" e nos sujeitos cérebro-lesados.

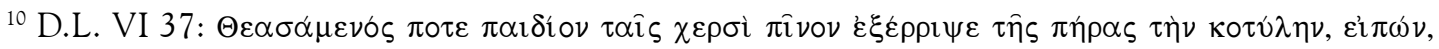

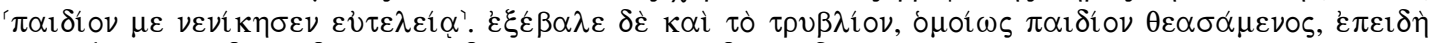

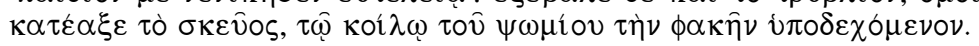


correto. ${ }^{11}$ Logo, se o filósofo renuncia até àquilo que o homem comum julga necessário, imaginá-lo - trata-se bem de "imaginar", já que não há, nas fontes antigas, qualquer referência nesse sentido - acumulando de maneira desordenada objetos inúteis seria um verdadeiro contrasenso. Note-se ainda que a recorrência desse motivo - uma criança que dá ao filósofo uma lição de simplicidade -, reelaborado em diferentes versões por outros autores, parece confirmar a importância que Diógenes acordava a um modo de vida regido pela frugalidade e pelo despojamento extremos. ${ }^{12}$ Esse modo de vida, marcado então pela renúncia ao supérfluo

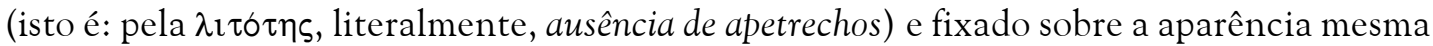
do filósofo, será um dos traços distintivos do cinismo, tal como confirma ainda Diógenes Laércio, ao resumir os fundamentos da escola na conclusão do livro que ele lhe consagra:

Eles [os cínicos] sustentam que convém viver frugalmente ( $\lambda \imath \tau \omega \varsigma \varsigma$ ßrov̂v), com alimentos que podem ser obtidos pela própria pessoa e de posse de um só manto, e desprezar riqueza, fama e nobreza de nascimento. Alguns, de fato, se satisfazem com ervas e água fresca, com abrigos improvisados ou tonéis, como Diógenes, que dizia ser próprio dos deuses não precisar de nada, e dos que se parecem com os deuses precisar de pouco. ${ }^{13}$

Diógenes condena, assim como os cínicos em geral, todo tipo de acumulação, de entesouramento. E não deixaria de acusar - provavelmente surpreso diante da denominação que recebeu - a doença no comportamento dos que se entregam ao ajuntamento de coisas sem serventia, da mesma forma que comparava a avareza à hidropsia: com efeito, tanto os avaros como os hidrópicos - e também os tiranos que, no dizer de Antístenes, são acometidos de uma terrível enfermidade $(\chi \alpha \lambda \varepsilon \pi \eta \dot{\eta} \nu \sigma o \sigma \varsigma)^{14}$ - padecem de um mal idêntico, o de querer sempre mais daquilo de que eles já estão repletos. ${ }^{15}$

Crates de Tebas, filósofo cínico e poeta, que, segundo algumas fontes, teria sido discípulo direto de Diógenes de Sínope, ${ }^{16}$ traduz em verso esse fundamento da doutrina cínica; trata-se, na verdade de uma paródia, justamente famosa, da Elegia às Musas do poeta e legislador Sólon de Atenas, ${ }^{17}$ e que foi conservada por duas citações do Imperador Juliano (séc. IV d.C.), uma no Contra o cínico Heráclio e outra no Contra os cínicos ignorantes. Eis o trecho que nos interessa:

${ }^{11}$ D.L. VI 35.

${ }^{12}$ M.-O. Goulet-Cazé, "Le livre VI de Diogène Laërce: analyse de sa structure et réflexions méthodologiques" (ver principalmente as pp. 4029-4039) examina precisamente esse apophthegma para comentar os processos de formação da literatura cínica, tendo recenseado outras seis versões para o mesmo episódio: Sêneca, Carta a Lucílio 90, 14; Plutarco, De profectibus in virtutem 8, p. 79e; Gnomologium Vaticanum 743, n. 185; Jerônimo, Adversus Joviniamum II 14; Simplício, In Epicteti enchiridion commentarium 32; Basílio, Carta I 14. Sobre a frugalidade e o modo de vida de Diógenes, ver os fragmentos reunidos em SSR V B 152-195.

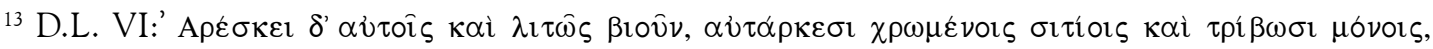

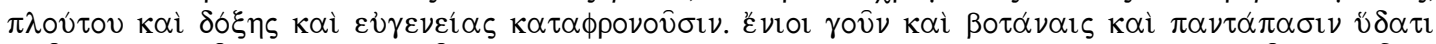

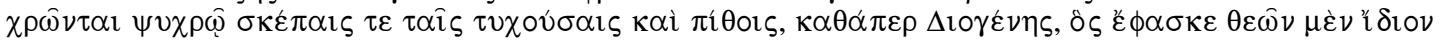

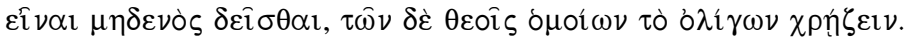

${ }^{14}$ Cf. Xenofonte, Banquete IV 35-37.

${ }^{15}$ Cf. Estobeu III 10, 45 (SSR V B 229).

${ }^{16}$ Cf. D.L. VI 85.

${ }^{17}$ Fr. 13 West (fr. 1 Diehl). 
Bens gloriosos não quero acumular, buscando avidamente

a felicidade do besouro e a opulência da formiga;

mas sim dividir a justiça e recolher a riqueza

fácil de levar, fácil de achar, um lustro para a virtude. ${ }^{18}$

Comentei recentemente a elegia de Crates para retomar aqui apenas alguns de seus aspectos, observados naquela ocasião, que julgo ilustrarem a impropriedade da denominação da "síndrome de Diógenes". ${ }^{19}$

Em primeiro lugar, cabe notar que estamos diante de um verdadeiro elogio à pobreza, ou, mais precisamente, diante da afirmação de que a verdadeira riqueza consiste em ser pobre; nesse sentido, Crates não faz mais do que reiterar a opinião de Antístenes, um "proto-Cínico"zo

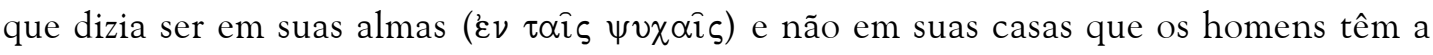
riqueza ou a pobreza. ${ }^{21}$ Oferecendo um belo exemplo do kynikòs trópos, do qual, no plano literário, a paródia é uma das expressões, ${ }^{22}$ Crates subverte a moral veiculada por Sólon, para quem toda riqueza obtida justamente é justa; para o cínico, ao contrário, o problema da justiça da obtenção da riqueza não se coloca, pois a riqueza, sendo uma forma de acumulação e excedendo por definição o necessário, é, de saída, injusta. O sábio deve, diversamente do que a maioria dos homens tende a fazer, investir na verdadeira riqueza que é constituída pela virtude; a virtude, por sua vez, implica, de um lado, na força de se contentar com o necessário e, de outro, no estar preparado para toda eventualidade. Sua riqueza será então "fácil de levar, fácil de achar": em sentido abstrato ela corresponde à própria virtude da alma, finalidade de um exercício constante, de uma ascese rigorosa, e, concretamente, ao essencial para a vida. $\mathrm{Na}$ contramão de Sólon, que em sua elegia solicita das Musas a "felicidade que vem dos deuses bem-aventurados”, identificando-a com riqueza e boa reputação, Crates, na sua paródia, nos versos que antecedem os citados, pede às deusas um simples e vulgar $\chi$ óptos, ou seja, um pouco de erva fresca ou seca com que possa cotidianamente acalmar as urgências de seu estômago.

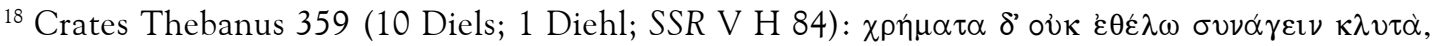

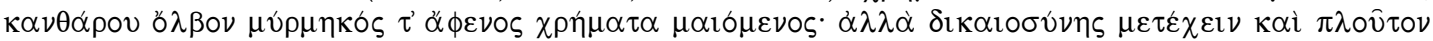

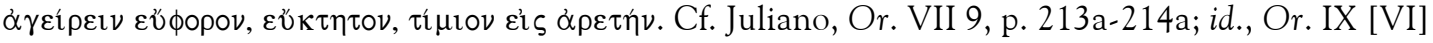
17, p. 199c-200b (SSR V H 84).

${ }^{19}$ Cf. O. Flores-Júnior, "Cratès, la fourmi et l'escarbot: les cyniques et l'exemple animal".

${ }^{20}$ A tradição mais difundida, da qual Diógenes Laércio se faz depositário (cf., por exemplo, D.L. II 15; VI 15; VI 21), num esforço escolar de organização, traça uma linha contínua levando de Sócrates ao estoicismo, estabelecedno a difundida sucessão discipular: Sócrates, Antístenes, Diógenes de Sínope, Crates, Zenão estóico. No entanto, o estudo de D.R. Dudley, A history of cynicism, questiona, com bons argumentos, essa tradição que identifica em Antístenes o primeiro cínico. A crítica mais recente tende a considerar que, se a doutrina cínica não existe antes de Diógenes, não se pode negar que o pensamento ético de Antístenes tenha exercido uma influência importante sobre o filósofo de Sínope: cf. G. Giannantoni, "Antistene fondatore della scuola cinica?”, em M.-O. Goulet-Cazé e R. Goulet (eds.), Le Cynisme ancien et ses prolongements, p. 1554; K. Döring, "Diogenes und Antisthenes", em G. Giannantoni et alii, La tradizione socratica, p. 125-150 e M.-O. Goulet-Cazé, "Who was the first dog?", em R. Bracht Branham e M.-O. GouletCazé (eds.), The Cynics. The Cynic movement in Antiquity and its legacy, p. 414-415.

${ }^{21}$ Xenofonte, Banquete IV 34.

${ }^{22}$ Cf. J. Roca Ferrer, Kynikòs trópos. Cynismo y subversión literaria en la antigüedad. Crates recorreu outras vezes à paródia como veículo de transmissão da doutrina cínica: cf., por exemplo, o poema Pera em D.L. VI 85, elaborado a partir de alguns versos homéricos (Od. XIX 172 e ss.). 
Mas o estômago do cínico, trabalhado pela constância da ascese, contenta-se de pouco, garantindo-lhe uma "uma vida frugal, longe da escravidão". ${ }^{23}$ Considerado o esforço exigido pela aquisição e pela manutenção da riqueza material, ${ }^{24}$ compreende-se que, da perspectiva cínica, é a pobreza que conduz à liberdade e à autarquia. A riqueza representa, portanto, um sofrimento ( $\pi$ óvos) inútil que a aceitação da pobreza, um esforço ( $\pi$ óvos) útil, pode combater. ${ }^{25}$

Um outro aspecto do poema de Crates sobre o qual convém se deter um momento, no esforço de compreender a impropriedade da relação entre o cinismo histórico e um "colecionismo mórbido", é a referência à "felicidade do besouro" e à "opulência da formiga", ambas peremptoriamente recusadas pelo poeta-filósofo. Por que esses dois animais? A formiga e o besouro são animais tradicionalmente conhecidos pelo hábito que têm de guardar e acumular seu alimento, evocando, no imaginário popular, um temperamento previdente ou

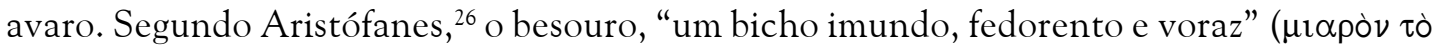

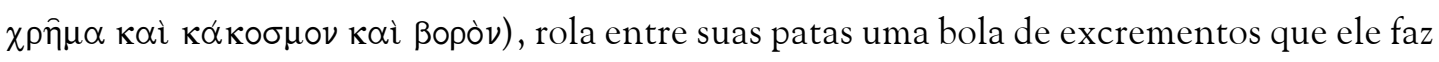
progressivamente aumentar e que ele come em seguida com voracidade; Eliano confirma esse comportamento e acrescenta que o besouro se compraz de tal modo em meio ao fedor que se alguém derramar perfume sobre ele, ele morre; ${ }^{27}$ enfim, o cínico Enomau de Gadara, ao comentar a importância que tinham para os gregos questões sobre a autoctonia ou sobre a terra na qual seriam sepultados, afirma que os besouros sempre vivem e morrem no estrume. ${ }^{28}$ Quanto à formiga, Eliano lembra sua economia metódica ${ }^{29}$ e menciona uma espécie indiana, aparentemente conhecida também de Heródoto, de que uma das características é guardar e vigiar quantidades de ouro. ${ }^{30} \mathrm{Em}$ uma das fábulas de Esopo, a formiga "era antes um homem que, praticando a agricultura, não se contentava do produto de seu próprio trabalho, invejava o dos outros e sempre roubava o fruto de seus vizinhos"; ${ }^{31} \mathrm{em}$ outra fábula, a imagem da formiga laboriosa que, durante o verão, acumula trigo e cevada para o inverno, se opõe àquela do besouro que, fugindo do trabalho e buscando uma vida fácil, sofre depois com a fome. ${ }^{32}$

Através do contra-exemplo fornecido pelo comportamento da formiga e do besouro, Crates reafirma a recusa de toda acumulação. Da perspectiva cínica, o homem que se empenha em adquirir ou acumular riquezas incorre, de dois, em pelo menos um erro: em primeiro lugar, conservando o que ultrapassa a sua estrita necessidade, ele cede ao vício da avareza e acaba por usurpar, direta ou indiretamente, o que pertence a outros; ${ }^{33}$ por outro

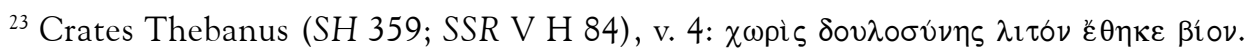

${ }^{24}$ Cf. o discurso de Cármides, um "ex-rico", em Xenofonte, Banquete IV 29-33. Cf. ainda Sêneca, De tranquillitate animi VIII 3-5, que comenta a "pobreza" de Diógenes.

${ }^{25}$ Sobre o assunto, ver M.-O. Goulet-Cazé, L’ascèse cynique, p. 53-76.

${ }^{26}$ Cf. Aristófanes, A paz 1-40.

${ }^{27}$ Cf. Eliano, A personalidade dos animais I 38; IV 18; VI 46; X 15.

${ }^{28}$ Cf. Enomau, apud Eusébio, Praeparatio evangelica V 33, 16-17.

${ }^{29}$ Cf. Eliano, op. cit., II 25.

${ }^{30}$ Cf. Eliano, op. cit., III 4; Heródoto III 102-105.

${ }^{31}$ Cf. Esopo, fábula 240 Chambry.

${ }^{32}$ Cf. Esopo, fábula 241 Chambry.

${ }^{33}$ Ver, sobre esse ponto, a alegoria do anfitrião generoso elaborada pela personagem designada simplesmente como "Cínico" no pequeno diálogo do (pseudo-)Luciano, O Cínico (cf. o passo 5), do qual eu mesmo propus uma tradução: O. Flores-Júnior, Luciano, O Cínico. 
lado, se o que o move é a previdência e a busca de uma segurança futura, ele incorre simplesmente em estupidez, pois, como o próprio Sólon reconhece, na mesma elegia parodiada por Crates, o futuro é imprevisível e os desígnios dos deuses são insondáveis. Contra a insegurança da existência e o mal de estar no mundo, o antídoto que o cinismo oferece vem, não do excesso, mas do mínimo. Por outro lado, se Crates menciona em seus versos apenas os "bens gloriosos" é porque o alvo de sua crítica é a loucura dos sãos: para ele, tanto o capitalista voraz quanto o poupador previdente ameaçam mais a cidade do que o velho que, com a idiossincrasia de seu colecionismo, empilha em casa restos de sua história pessoal ou o lixo jogado por outros; mas a rigor, aos olhos do cínico, o esforço de juntar dinheiro equivale ao de amontoar velhas embalagens e sobras de comida, e ambos não passam de felicidade de besouro e opulência de formiga.

Outros sintomas da "síndrome de Diógenes" poderiam ser examinados aqui à luz da literatura cínica, como por exemplo a negligência pessoal e domiciliar ou o isolamento social - para o primeiro caso, não faltariam evidências textuais que demonstram que a ascese cínica visa em primeiro lugar à saúde e ao fortalecimento corporal, para que o corpo não seja um entrave às decisões morais da pessoa; ${ }^{34}$ para o segundo, bastaria dizer que a missão que Diógenes se atribuía era a de admoestar os homens e que uma missão assim só ganha pleno sentido no contexto da cidade, no corpo-a-corpo das ruas e no fervilhamento das praças $^{35}$-, mas o resultado do exame levaria à mesma conclusão a que chegamos ao submeter a syllogomania dos pacientes "Diógenes" ao crivo da filosofia do Diógenes histórico: na denominação da síndrome que leva seu nome, a apropriação do elemento histórico redundou não num equívoco de detalhe ou, como é mais freqüente, em uma leitura, escolhida em meio a outras possibilidades, mas numa verdadeira inversão, cujo saldo é a supressão do sentido de uma das mais radicais formas de racionalidade prática que o pensamento ocidental produziu.

Da "síndrome de Diógenes" ao "gozo cínico". Num estudo recente, que tem por objeto o problema da toxicomania nas sociedades contemporâneas, a filosofia de Diógenes é tomada de empréstimo para descrever a relação do toxicômano com a droga, entendida como uma "parceria cínica na era da ciência". ${ }^{36}$ Depois de revisar a literatura psicanalítica sobre o problema da toxicomania, passando obviamente por Freud e Lacan, o autor elabora a sua própria visão do assunto, de cujo contexto emerge a idéia segundo a qual "o gozo, no fato toxicomaníaco, pode encontrar-se no horizonte do gesto masturbatório público de Diógenes". ${ }^{37}$ Acertadamente, ele reconhece no gesto de Diógenes uma mensagem moral, uma demonstração de ordem ética, que, frente à ontologia e à teoria do conhecimento platônicas, "pressupõe a reabilitação do corpo sob a forma de uma técnica destinada a lhe ser

\footnotetext{
${ }^{34}$ Sobre o assunto, consultar M.-O. Goulet-Cazé, L'ascèse cynique, p. 210-222.

${ }^{35}$ Veja-se, por exemplo, o artigo de S. Husson, "La politeia de Diogène le Cynique", em G. Romeyer Dherbey (dir.) e J.-B. Gourinat (ed.), Socrate et les socratiques, Paris, 2001, pp. 411-430, com o qual, no entanto, não estou inteiramente de acordo.

36 J. Santiago, A droga do toxicômano. Uma parceria cínica na era da ciência, que reproduz essencialmente a tese de doutoramento do autor, defendida em julho de 1992 junto ao Departamento de Psicanálise da Universidade de Paris VIII, sob a orientação de Serge Cottet: J. Santiago, Drogue, science et jouissance: sur la toxicomanie dans le champ freudien.

${ }^{37}$ J. Santiago, A droga do toxicômano. Uma parceria cínica na era da ciência, p. 156.
} 
aplicada"; ${ }^{38}$ reconhece, portanto, a importância da ascese no cinismo, que implica a máxima redução das próprias necessidades, e que pode conduzir à realização dos ideais de autarquia, liberdade e ausência de perturbação. Observa, também corretamente, que "o atalho cínico para a felicidade não pede nem longos discursos, nem conhecimentos, mas um domínio do corpo capaz de evitar os dois maiores inimigos do homem: o prazer e o sofrimento". ${ }^{99}$ Afirma, enfim, embora sem aduzir qualquer evidência textual - o que seria bem-vindo, no caso de um tema complexo como é o do prazer no cinismo -, que o "ponto de partida da ascese cínica é uma espécie de intuição referente à distinção entre prazer e gozo". 40

Se a apreciação geral do cinismo é, no seu conjunto, aceitável, apesar de algumas imprecisões histórico-filosóficas ${ }^{41}$ - de menor alcance, é certo, no caso de um estudo cujo terreno é o da psicanálise -, a consideração do "gesto masturbatório" de Diógenes parece-me problemática. Em primeiro lugar, afirmar que "o ato masturbatório encarna o preceito ascético da renúncia do Outro" ${ }^{42}$ soa, ao mesmo tempo, óbvio e impreciso, já que a masturbação consiste num prazer solitário, mas que pode evocar, pela imaginação ou por algum processo de substituição (uma fotografia, por exemplo), a presença do "Outro"; em todo caso, não está claro o porquê de se utilizar a imagem de Diógenes se masturbando para ilustrar o que já está contido no ato mesmo de qualquer masturbação. O contra-argumento é dado pelo próprio texto: Diógenes se masturba em público. Mas também aí, o empréstimo torna-se inócuo, já que o que difere o "gozo cínico" do gozo do toxicômano da era da ciência é que este, cedendo à sedução do mercado, se satisfaz "à margem, no seu canto, não tem a menor intenção de demonstração". Enfim, a masturbação pública de Diógenes não é "apenas um gesto de insolência no lugar da ilusão da sublimação". ${ }^{43}$

O caráter público de toda ação cínica tem uma função pedagógica na qual a insolência desempenha um papel importante: o filósofo cínico visa, de algum modo, a despertar os

${ }^{38}$ Ibid., p. 157.

${ }^{39}$ Ibid., p. 157.

${ }^{40}$ Ibid., p. 157.

${ }^{41} \mathrm{O}$ conjunto das referências à literatura cínica deixa entrever uma certa flutuação no uso de dois nomes próprios recorrentes: o do filósofo cínico, Diógenes de Sínope (séc. IV a.C.) e o do biógrafo e historiador da filosofia, Diógenes Laércio (que viveu provavelmente no séc. III d.C.), autor das Vidas e doutrinas dos filósofos ilustres; na "orelha" do livro, lê-se: "O tratamento cínico do mal-estar do desejo, hoje, não é mais o que era para o sábio da Antigüidade Diógenes Laércio". Além disso, o estudo refere-se à "sabedoria socrática" para indicar a doutrina de Platão, que Diógenes combateria (p. 157); na verdade, do ponto de vista histórico e segundo a tradição melhor documentada, tanto o platonismo quanto o cinismo têm sua origem no ensinamento de Sócrates; a rigor, não se pode pretender que o pensamento plaônico venha a subsumir o de Sócrates. Enfim, a explicação colhida na Encyclopédie Philosophique Universelle - L'Univers Philosophique, Paris: PUF, t.I, p. 539, para o nome "cínico", simplifica as coisas, excluindo, por exemplo, a hipótese baseada na denominação do Cinosarges, o ginásio situado na periferia de Atenas, que Antístenes freqüentava; sobre o assunto, podem ser consultadas as seguintes obras: G. Giannantoni, "Antistene fondatore della scuola cinica?" em M.-O. Goulet-Cazé e R. Goulet (eds.), Le cynisme ancien et ses pronlogements, p. 15-34 e M.-F. Billot, "Antisthène et le Cynosarges dans l'Athènes des $V^{e}$ et IVe siècles" em M.-O. Goulet-Cazé e R. Goulet (eds.), op. cit., pp. 69-116.

${ }^{42}$ J. Santiago, op. cit., p. 158.

${ }^{43}$ Ibid., p. 158. 
homens de seu torpor moral, chamando a atenção para o que pode haver de automático e de irrefletido em seu comportamento; a insolência, assim como a derrisão são, nesse sentido, instrumentalizados para uma finalidade ética. O próprio Diógenes dizia ser um cão que, diferentemente dos outros cães, morde seus amigos a fim de salvá-los ${ }^{44}$ e Luciano definia o filósofo cínico como um cão que morde rindo. ${ }^{45}$ Mas a publicidade do gesto cínico encerra, para além de seu valor pedagógico, uma dimensão propriamente ética, como demonstra a seguinte passagem, colhida na obra de Diógenes Laércio:

Ele [Diógenes] tinha o hábito de fazer tudo em público, mesmo as obras de Deméter e as de Afrodite, colocando a questão nos seguintes termos: se nada há de estranho em fazer uma refeição, nada há de estranho em fazê-la em praça pública; ora, fazer uma refeição não é estranho, logo não é estranho fazer uma refeição em praça pública. ${ }^{46}$

Diógenes suprime do plano ético a distinção convencional entre o público e o privado, substituindo-a por outra, fundada na justiça ou injustiça de qualquer ação: o cínico come em público porque é justo comer, da mesma forma que ele pratica o sexo em público porque praticar o sexo é justo. Mas essa passagem contém ainda um outro elemento que interessa observar no esforço de se compreender os limites da apropriação do "gozo" dos cínicos pelo viés psicanalítico. O texto fala não de masturbação, mas de "obras de Afrodite", que poderiam, talvez, incluir a masturbação, mas que se referem prioritariamente ao sexo com o outro, uma vez que a deusa evocada preside "entre homens e Deuses imortais, as conversas de moças, os

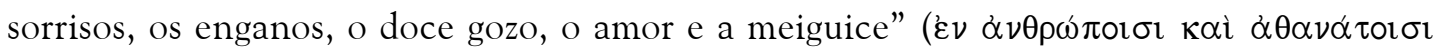

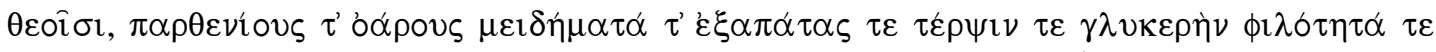
$\mu \varepsilon \imath \lambda \iota \chi i$ $\eta \nu \tau \varepsilon) ; 47$ trata-se, pois, de uma divindade ligada à sedução. À imagem do onanista incorrigível - cujo ato, entretanto, "não se confunde com a atitude imoral do canalha"48 que, recusando a "sublimação da civilização", suprime o encontro com o "Outro", deve-se sobrepor a do filósofo que, sem rejeitar o gozo com o outro, entrega-se eventualmente, se a ocasião exigir, à satisfação solitária, cuja legitimidade autoriza a cena aberta.

A literatura antiga testemunha, com outras referências, a "versatilidade" sexual que Diógenes pregava e, sem dúvida, praticava - entre os cínicos, as duas esferas, a do discurso e a da ação, tendem a coincidir: a vida do filósofo é, de certo modo, a verificação de sua doutrina. ${ }^{49}$ Filodemo de Gadara, epicurista do século I a. C., num texto manifestamente polêmico, afirma, aludindo à República de Diógenes, que o cínicos (e também os estóicos, sobretudo os das três primeiras gerações da escola), além de se masturbarem em público, consentiam na relação sexual com a própria mãe, com irmãs, irmãos, com os próprios filhos

${ }^{44}$ Cf. Estobeu III 13, 44 (SSR V B 149).

${ }^{45}$ Cf.Luciano, Dupla acusação 33.

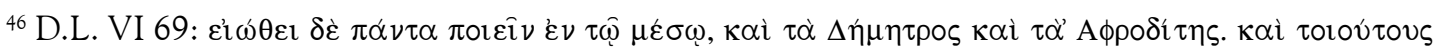

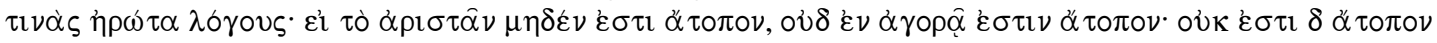

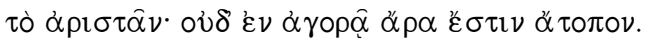

${ }^{47}$ Hesíodo, Teogonia 204-206.

${ }^{48}$ J. Santiago, op. cit., p. 159.

${ }^{49}$ Cf. D.L. VI 28; VI 64; VI 71; VI 104. 
e com qualquer parente; e que, em termos de sexo, nada deveria ser excluído. ${ }^{50} \mathrm{O}$ texto de Filodemo é, não há dúvida, hostil ao cinismo - trata-se de um epicurista, que toma partido no debate entre escolas que caracteriza a filosofia helenística - e, nesse sentido, ele parece deformar os seus aspectos mais controversos, forçando o traço naquilo que ele poderia ter de mais escandaloso; deforma, mas não inventa. Em todo caso, encontramos aí um depoimento sobre a extrema liberdade com que Diógenes abordava as questões relativas à sexualidade.

Ainda no registro doxográfico, Diógenes Laércio, remontando com certeza à mesma República, nos informa que:

[Diógenes de Sínope] dizia que as mulheres devem ser comuns, não dando nenhum crédito ao casamento, mas à união do homem que persuade com a mulher que é persuadida. ${ }^{51}$

O texto do biógrafo confirma, mas num estilo sóbrio e imparcial, o essencial daquilo que Filodemo faz render para servir à sua causa: permanece a mesma liberdade, mas redesenhada pelo jogo do consentimento que deve presidir as relações amorosas. É curioso observar que enquanto o texto laerciano fala em "consentimento", o de Filodemo é explícito ao afirmar que, para os cínicos, no que diz respeito às relações sexuais, mesmo a violência ( $\beta i ́ \alpha)$ seria admitida. ${ }^{52} \mathrm{O}$ próprio Antístenes já ensinava que o certo é "se unir às mulheres que darão

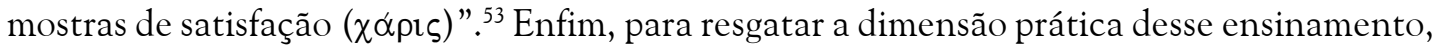
cuja importância é capital para os cínicos, convém lembrar a filósofa Hipárquia, que abraça o cinismo ao apaixonar-se por Crates, com quem tinha o hábito de se unir em público. ${ }^{54}$

A esta altura, é força constatar que o "gozo cínico" não se reduz a um "gesto masturbatório" e não recusa, a cada vez, a relação com o "Outro", o que de toda evidência escapou à descrição do psicanalista.

Mas a falha da apropriação reside, a meu ver, ainda num outro ponto: no fato de que, na exposição da hipótese psicanalítica, o episódio que descreve o "ato masturbatório" de Diógenes tenha sido amputado de sua parte mais significativa. Voltemos, como convém, à letra do texto antigo:

Diógenes se masturbava constantemente em público e dizia: "como seria bom se, esfregando assim a barriga, a fome passasse!". ${ }^{55}$

Não é apenas a masturbação que deve aqui ser levada em conta, mas também - e principalmente - a reflexão que a acompanha; é essa reflexão que, em última instância,

${ }^{50}$ Filodemo, De stoicis col. XVIII 9-25 Dorandi. Este texto, conservado fragmentariamente em dois papiros de Herculano, foi editado, traduzido (em italiano) e comentado por T. Dorandi, Filodemo. Gli stoici (PHerc. 155 e 339). Veja-se também o estudo recente de M.-O. GouletCazé, Les kynika du stoïcisme.

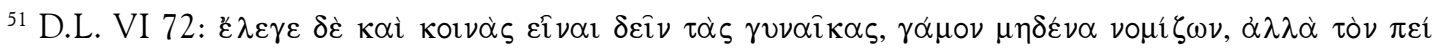

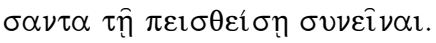

${ }^{52}$ Filodemo, De stoicis col. XVIII 25-26 Dorandi.

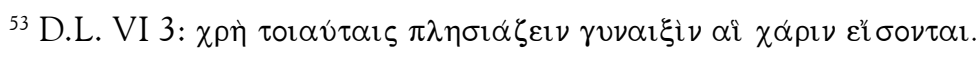

${ }^{54}$ Cf. D.L. VI 96-98.

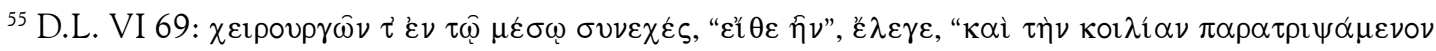

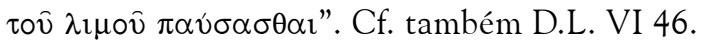


confere ao gesto o seu traço distintivo - não se trata de uma masturbação qualquer - e o seu caráter filosófico. Antes de mais nada, convém observar que Diógenes aproxima duas ordens de desejo, o do sexo e o da comida, tal como fica claro na outra passagem, citada mais acima, que fala do hábito do cínico de fazer em público tanto as "obras de Afrodite" quanto "as de Deméter”. Embora sem a sistematização que encontramos, por exemplo, em Epicuro, ${ }^{56}$ Diógenes sabe que, do ponto de vista das necessidades humanas, a sexualidade não tem o mesmo estatuto que a alimentação: enquanto a fome é um desejo natural e necessário, de que depende a vida mesma, a sexualidade envolve um desejo natural e não necessário; o desejo sexual poderia ser considerado necessário apenas do ponto de vista do conjunto dos homens - na

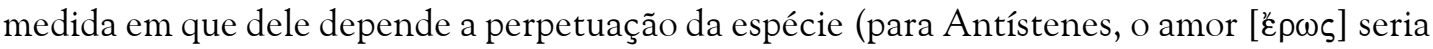

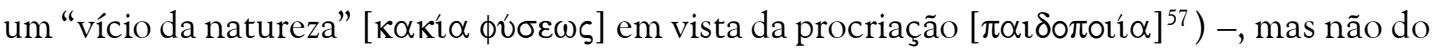
ponto de vista do indivíduo. Os cínicos, visando a uma vida tranqüila, podem até recomendar a abstinência e o celibato, ${ }^{58}$ mas não deixam de reconhecer que poucos homens serão capazes de praticá-los: ${ }^{59}$ o próprio Diógenes, segundo algumas fontes, mantinha relações com a cortesã Laís. ${ }^{60}$

Associando alimentação e sexualidade, os cínicos aplicam a esta, da qual os homens dificilmente se livram, a mesma economia que aplicam àquela, da qual os homens não podem, por natureza, escapar: pautando suas vidas pelo princípio da simplicidade e da austeridade, que o grego exprime pela já mencionada litótes, eles recomendam que todos os desejos, reduzidos a um núcleo essencial, devem ser contentados da maneira mais fácil, mais simples. Para satisfazer seu estômago, o cínico tem a força de, movimentando-se para o mais baixo, contentar-se, a exemplo do filósofo-poeta Crates, com um vulgar khórtos, a forragem grosseira destinada normalmente aos animais ${ }^{61} \mathrm{ou}$, de, se a ocasião exigir, ultrapassar o limite último da civilização - que a rigor exprime menos a natureza do que a convenção - e degustar a carne humana. ${ }^{62}$ Mas pode, da mesma forma, sem qualquer constrangimento e sem que isso constitua um relaxamento circunstancial de sua doutrina, movimentar-se para o alto - alto e baixo aqui correspondem justamente à hierarquia que o cinismo subverte - e matar a fome

${ }^{56}$ Cf. a distinção entre os vários tipos de prazer proposta por Epicuro em D.L. X 127-128. Há inegavelmente alguns pontos de contato entre a doutrina cínica e o epicurismo, mas os cínicos jamais elaboraram uma ética sistemática e uma escola cínica, no sentido material do termo, nunca existiu; sobre o assunto, ver M. Gigante, "Cinismo e Epicureismo" em M.-O. Goulet e R. Goulet (eds.), Le cynisme ancien et ses prolongements, p. 159-223.

${ }^{57}$ Cf. Clemente de Alexandria, Stromata II 20, 107, 3 e Teodoreto, Graecorum affectionem curatio III 53 (SSR V A 123).

${ }^{58}$ Cf. D.L. VI 29; Máximo de Tyro, Philosophumena XXXVI 5 (SSR V B 299).

${ }^{59}$ Cf. Pseudo-Diógenes, Carta 47, a Zenão (SSR V B 577). O uso das cartas cínicas pseudepígrafes, escritas por diferentes autores entre os séculos I a.C e II d.C., é metodologicamente problemático quando se pretende estudar o cinismo histórico, mas como escreve M.-O. Goulet-Cazé, L'ascèse cynique p. 19, n. 8 , "comme tout pastiche, elles avaient le souci de paraitre authentiques et elles devaient par conséquent s'inspirer au maximum de la littérature cynique connue à l'époque".

${ }^{60}$ Cf. Ateneu XIII 588c; Theophylactus, Carta LX (SSR V B 213).

${ }^{61}$ Cf. Heródoto IX 41; Hipponax, frag. 26 Masson; Xenofonte, Ciropedia VIII 6, 12; Plutarco, Adversus Colotem, passim; Antologia Palatina XI 413.

${ }^{62}$ Cf. D.L. VI 73; VII 121; Filodemo, De stoicis XVI 20-XVII 4 Dorandi; Teófilo, Ad Autolicum 3, 5 (SVF III 750; SSR V B 134). 
com "pãezinhos de mel", que no registro alimentar representam a quintessência da sofisticação. ${ }^{63}$

Num certo sentido, o cinismo de Diógenes radicaliza aquilo que já está presente em Antístenes, cujo pensamento foi preservado numa passagem luminosa do Banquete de Xenofonte. Fala Antístenes:

“(...) se porventura o meu corpo sente o desejo de gozar dos prazeres do amor, a primeira que aparece ( $\tau \dot{\partial} \pi \alpha \rho \delta$ v) resolve meu caso, tanto que as mulheres com as quais eu vou me acolhem com mil favores, já que ninguém mais se dispõe a ir com elas. (...) E quando busco prazer, eu não compro no mercado produtos de primeira escolha, que são muito caros, mas encontro esse prazer no meu apetite. E ele me traz um prazer muito maior quando eu como depois de ter esperado com paciência a necessidade de comer do que quando me sirvo de alguma coisa cara, como agora, que bebo sem sede este vinho de Tasso". ${ }^{64}$

A passagem nos sugere que a ascese posta em prática no cinismo visa a ensinar aos homens que a virtude só pode ser atingida no contexto de uma vida frugal ( $\lambda \imath \tau$ tò $\beta$ ß́os) e que nele o

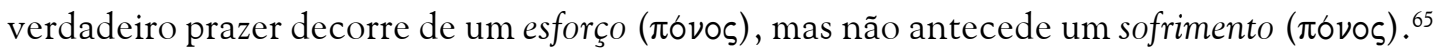
A vida frugal que os cínicos propõem depende, na verdade, de uma adequação àquilo que o grego traduz pela participial $\tau \propto \alpha$ $\pi \alpha \rho o ́ v \tau \alpha$ : as coisas presentes, o momento presente, o que se tem ao alcance da mão. A razão cínica não nega a "sublimação da civilização", nem propõe que o exercício do "gozo" e do "prazer" excluam o "Outro" de seu horizonte. Ela apenas ensina aos homens uma outra economia dos desejos. A masturbação de Diógenes converte-se assim num instrumento dessa economia:

Não só o pão, a água, a cama feita de palha e o manto surrado ensinam a temperança e a firmeza; há ainda, se é necessário dizê-lo, a 'mão do pastor'. ${ }^{66}$

A "mão do pastor" é a kheirourgia que Pã ensinou àqueles que, por força de seu ofício, se vêem por longos períodos privados do comércio com o outro.

Após esse rápido percurso pelas apropriações contemporâneas do cinismo antigo, a conclusão a que chegamos é simples e apenas confirma o que de início se podia intuir: a "síndrome de Diógenes" busca na antigüidade uma filosofia mas dela nos entrega uma imagem rigorosamente invertida com relação ao que na origem constituía a sua essência; por outro lado, a idéia de "gozo cínico", desconsiderando certos textos e recortando outros, decalca da

${ }^{63}$ Cf. D.L. VI 44; VI 56; Gnomologium Vaticanum 743, n. 188 (SSR V B 189).

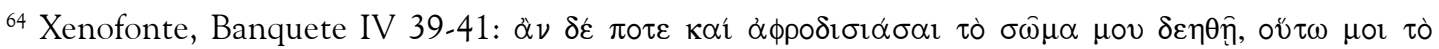

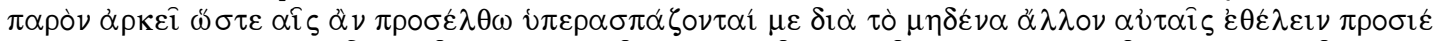

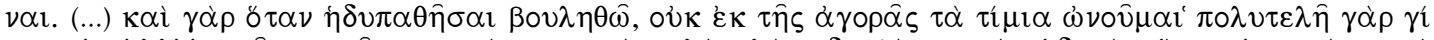

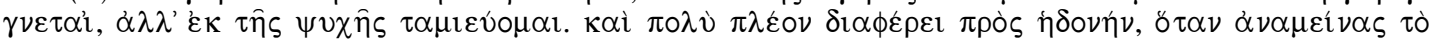

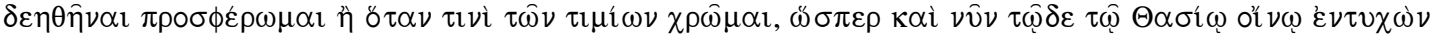

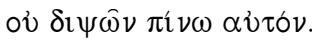

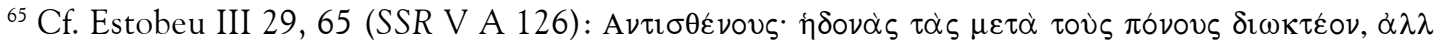

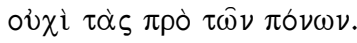

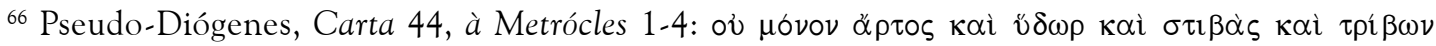

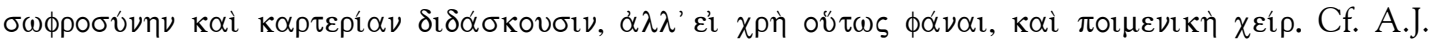
Malherbe, The Cynic epistles: a study edition, p. 174. 
literatura antiga não uma imagem invertida do cinismo histórico, mas um cinismo deturpado, empobrecido na sua dimensão filosófica, que decorre da instrumentalização a que foi submetido.

Todavia, duas observações se impõem: em primeiro lugar, é necessário explicar que a análise das formas pelas quais o discurso científico se apropria do fenômeno histórico não pode aqui ser tomada como uma invalidação - e nem mesmo como crítica - do real conteúdo desse discurso, que só poderia ser levada a termo por um outro discurso científico de igual competência, articulado segundo uma "simpatia" metodológica. Cabe, portanto, aos psiquiatras e psicanalistas a apreciação do valor propriamente psiquiátrico e psicanalítico das teorias que o cinismo foi convidado a ilustrar.

A segunda observação concerne ao domínio mais vasto do que poderíamos chamar "memória cultural": cabe perguntar se os problemas históricos e filosóficos da apropriação da antigüidade que busquei demonstrar aqui não corresponderiam, de algum modo, à própria constituição da cultura, que, avançando "em retrocessos", projeta sobre a leitura do passado as interpretações elaboradas no presente e imprimem nele, às vezes de modo indelével, a marca de seus eventuais equívocos. O esforço de correção a que de tempos em tempos submetemos as nossas heranças dá a toda tradição seu inelutável caráter palimpséstico.

Para concluir esta minha breve reflexão, reato com os versos que lhe serviram de epígrafe: em meio às fantasmagorias da tradição e na lógica enviesada que preside aos processos culturais, bem pode a porca parir um burro. Mas com vinte e cinco mamas, de que muitos se nutriram e de que outros tantos ainda hão de se nutrir.

A

\section{RÉ S U MÉ}

En examinant particulièrement la "syndrome de Diogène" ainsi que l'idée de "jouissance cynique", utilisée pour définir le toxicomane des sociétés actuelles, cet article reprend brièvement le problème de la lecture et de l'appropriation de l'antiquité classique dans la caractérisation des phénomènes culturels contemporains (ou, du moins, ceux décrits dans la contemporanéité). Loin de toute intention critique face aux phénomènes décrits, car la perspective adoptée est celle de l'histoire de la philosophie et non pas celle du domaine spécifique de la psychiatrie et de la psychanalyse, on cherche à démontrer, par le renvoi systématique au texte des sources antiques - dans ce cas, au corpus cynique -, les limites méthodologiques et les équivoques qui découlent de cette pratique.

\section{MOT S - C LÉ S}

Cynisme, Diogène de Sinope, «Syndrome de Diogène», «Jouissance Cynique», Psychiatrie, Psychanalyse, Histoire de

la Philosophie, Appropriation. 


\section{REFERÊNCIAS BIBLIOGRÁFICAS}

AAVV. Bulletin d'Information en Santé Environnementale (BISE), v. 16, n. 2, p. 1-7, marsavril, 2005 (http://www.inspq.qc.ca/bulletin/bise/).

BILLOT, M.-F. "Antisthène et le Cynosarges dans l'Athènes des Ve et IVe siècles". In: M.-O. Goulet-Cazé e R. Goulet (eds). Le Cynisme ancien et ses prolongements. Paris: P.U.F., 1993.

BOLLACK, J. L' "Édipe Roi" de Sophocle. Le texte et ses interprétations. Col. Cahiers de Philologie, 11-13. Villeneuve-d'Ascq: Presses Universitaires de Lille, 1990, 4 v.

. La naissance d' Edipe. Traduction et commentaires d' "CEedipe Roi". Col. Tel. Paris: Gallimard, 1995.

CLARK, A. N., MANKIKAR, G. e GRAY, I. D. Diogenes syndrome: a clinical study of gross neglect in old age. The Lancet, London, v. 305, 1, p. 366-368, 1975.

DORANDI, T. Filodemo. Gli stoici (PHerc. 155 e 339), Cronache Ercolanesi, Napoli, n. 12, p. 91-133, 1982.

DÖRING, K. Diogenes und Antisthene. In: G. Giannantoni et alii. La tradizione socratica. Napoli: Bibliopolis, 1995.

DUDLEY, D.R. A history of Cynicism: from Diogenes to the $6^{\text {th }}$ century. $2^{\mathrm{a}} \mathrm{ed}$. Chicago: Agres Publishers, 1980.

FLORES-JÚNIOR, O. Luciano. O cínico. Kléos, Rio de Janeiro, v. 1, n. 1, p. 254-275, 1997.

. Paraxara/ttein to $\backslash$ no/misma ou as várias faces da moeda. Ágora, Aveiro, n. 2, p. 21 32, 2000.

. Sobre o problema das fontes no estudo do cinismo antigo. Kriterion, Belo Horizonte, n. 102, p. 190-215, 2000.

. Cratès, la fourmi et l'escarbot: les cyniques et l'exemple animal. Philosophie Antique, Paris, p. 135-171, 2005.

GIANNANTONI, G. Socratis et socraticorum reliquiae, collegit, disposuit, apparatibus notisque instruxit G. Giannantoni. Col. Elenchos, 18. Napoli: Bibliopolis, 1990, 4 v.

. Antistene fondatore della scuola cinica? In: M.-O. Goulet-Cazé e R. Goulet (eds). Le Cynisme ancien et ses prolongements. Paris: P.U.F., 1993.

GIGANTE, M. Cinismo e Epicureismo. In: M.-O. Goulet e R. Goulet (eds.), Le cynisme ancien et ses prolongements. Paris: P.U.F., 1993 (=id., Cinismo e epicurismo. Napoli: Bibliopolis, 1992). GOULET-CAZÉ, M.-O. L'ascèce cynique. Un commentaire de Diogène Laërce VI 70-71. Paris: Vrin, 1986.

. Le livre VI de Diogène Laërce: analyse de sa structure et réflexions méthodologiques. In: W. Haase (ed.), Aufstieg und Niedergang der römischen Welt II 36, 6, p. 3881-4048, Berlin: W. de Gruyter, 1992.

. Who was the first dog? In: R. Bracht Branham e M.-O. Goulet-Cazé (eds.). The Cynics. The Cynic movement in Antiquity and its legacy. Berkeley: University of California Press, 1996.

. Les kynika du stoïcisme. Col. Hermes Einzelschriften, 89. Stuttgart: Franz Steiner Verlag, 2003.

HÖISTAD, R. Cynic hero and cynic king. Uppsala: Lund, 1948. 
HUSSON, S. La Politeia de Diogène le Cynique. In: G. Romeyer Dherbey (dir.) e J.-B. Gourinat (ed.), Socrate et les socratiques. Paris: Vrin, 2001

LÉON, V., RANNOU-DUBAS, K., BARRÉ, J., GOHIER, B. GOEB, J.L. E GARRE, J.B. Un collectionnisme singulier: le syndrome de Diogène. Psychiatrie Angevine. Service de Psychiatrie et de Psychologie Médicale CHU Angers, 2003 (http://www.med.univ-angers.fr/services/AARP/ psyangevine/publications/diogenes.htm).

LONG, H.S. Diogenis Laertii Vitae Philosophorum recognovit brevique adnotatione critica instruxit H.S.L. Col. Oxford Classical Texts, Oxford: Clarendon Press, 1964, 2 v.

LLOYD-JONES, H. e PARSONS, P. Supplementum hellenisticum. Col. Texte und Kommentare, 11. Berlin: W. de Gruyter, 1983.

MacMILLAN, D. e SHAW, P. Senile breakdown in standards of personnal and environnemental cleanliness. British Medical Journal, London, n. 271, p. 1032-1037, 1966.

MALHERBE, A.J. The Cynic epistles: a study edition, Missoula: 1977.

PAQUET, L. Les cyniques grecs. Fragments et témoignages. 2a ed. Ottawa: Presses de l'Université d'Ottawa, 1990.

ROCA FERRER, J. Kynikòs trópos. Cynismo y subversión literaria en la Antigüedad. Col. Bolletin del Instituto de Estudios Helénicos, 8. Barcelona: Universidad de Barcelona, 1974.

SALADINI, O. e LUAUTE, J.P. Le collectionnisme des entasseurs pathologiques. Neuro-psy, Paris, n. 155, p. 246-252, 2000.

SALDANHA, N. Os clássicos e a exemplaridade histórica. Humanidades, v.1, n.1, p.28-36, 1983.

SANTIAGO, J. Drogue, science et jouissance: sur la toxicomanie dans le champ freudien. Paris: Université de Paris VIII, Département de Psychanalise, 1992 (thèse de doctorat nouveau régime).

SANTIAGO, J. A droga do toxicômano. Uma parceria cínica na era da ciência. col. "Campo Freudiano no Brasil”, Rio de Janeiro: Jorge Zahar, 2001.

TORRANO, J. Hesíodo. Teogonia. A origem dos Deuses, estudo e tradução de Jaa Torrano. 2a ed. São Paulo: Iluminuras, 1992, p.117.

VERNANT, J.-P. "Édipo” sem complexo. In: J.-P. VERNANT e P. VIDAL-NAQUET, Mito e tragédia na Grécia Antiga. Trad. A. L. de Almeida Prado, F. Y. Hirata Garcia e M. C. M. Cavalcante. São Paulo: Brasiliense, 1988.

WEST, M.L. Iambi et elegi Graeci ante Alexandrum cantati, v. II. Col. Oxford Classical Texts. Oxford: Clarendon Press, 1992. 